This item was submitted to Loughborough's Research Repository by the author.

Items in Figshare are protected by copyright, with all rights reserved, unless otherwise indicated.

\title{
Comparison of Cadmium Selenide Thin Films deposited by chemical bath and pulsed DC sputtering for use in Cadmium Telluride devices
}

\author{
PLEASE CITE THE PUBLISHED VERSION
}

https://doi.org/10.1109/pvsc45281.2020.9300466

PUBLISHER

IEEE

\section{VERSION}

AM (Accepted Manuscript)

\section{PUBLISHER STATEMENT}

Personal use of this material is permitted. Permission from IEEE must be obtained for all other uses, in any current or future media, including reprinting/republishing this material for advertising or promotional purposes, creating new collective works, for resale or redistribution to servers or lists, or reuse of any copyrighted component of this work in other works.

\section{LICENCE}

\section{All Rights Reserved}

\section{REPOSITORY RECORD}

Morris, Kerrie, Rachael Greenhalgh, Vladislav Kornienko, Christos Potamialis, Jake Bowers, and Michael Walls. 2021. "Comparison of Cadmium Selenide Thin Films Deposited by Chemical Bath and Pulsed DC Sputtering for Use in Cadmium Telluride Devices". Loughborough University. https://hdl.handle.net/2134/13603001.v1. 


\section{Comparison of Cadmium Selenide Thin Films Deposited by Chemical Bath and Pulsed DC Sputtering for use in Cadmium Telluride Devices}

\author{
Kerrie M. Morris \\ Centre for Renewable Energy Systems \\ Technology (CREST) \\ Loughborough University \\ Loughborough, UK \\ k.morris@lboro.ac.uk
}

Christos Potamialis

Centre for Renewable Energy Systems

Technology (CREST)

Loughborough University

Loughborough, UK

c.potamialis@lboro.ac.uk

\author{
Rachael C. Greenhalgh \\ Centre for Renewable Energy Systems \\ Technology (CREST) \\ Loughborough University \\ Loughborough, UK \\ r.c.greenhalgh@lboro.ac.uk
}

\author{
Jake W. Bowers \\ Centre for Renewable Energy Systems \\ Technology (CREST) \\ Loughborough University \\ Loughborough, UK \\ j.w.bowers@lboro.ac.uk
}

\author{
Vladislav Kornienko \\ Centre for Renewable Energy Systems \\ Technology (CREST) \\ Loughborough University \\ Loughborough, UK \\ v.kornienko@lboro.ac.uk \\ John M. Walls \\ Centre for Renewable Energy Systems \\ Technology (CREST) \\ Loughborough University \\ Loughborough, UK \\ j.m.walls@lboro.ac.uk
}

\begin{abstract}
Cadmium selenide (CdSe) thin films deposited using chemical bath deposition and pulsed DC magnetron sputtering are compared for use in cadmium telluride/selenide (CST) photovoltaic (PV) devices. Full devices were made from the bath and sputtered films using a cadmium chloride $\left(\mathrm{CdCl}_{2}\right)$ treatment temperature of $425^{\circ} \mathrm{C}$, this gave an overall efficiency of $9.3 \%$ and $3.2 \%$ respectively. Photoluminescence (PL) of the sputtered sample confirmed a bandgap was present of $1.58 \mathrm{eV}$ which suggested poor diffusion at $425^{\circ} \mathrm{C} . \mathrm{A}\left(\mathrm{CdCl}_{2}\right)$ treatment temperature of $465^{\circ} \mathrm{C}$ gave a large PL peak at $1.37 \mathrm{eV}$ which corresponds to the bandgap of CST, indicating diffusion was more effective at this temperature.
\end{abstract}

Index Terms-cadmium selenide, thin film, chemical bath, pulsed DC magnetron sputtering

\section{INTRODUCTION}

Cadmium telluride (CdTe) based photovoltaics have seen an increase in efficiency in recent years with a record breaking $22.3 \%$ [1]. The increase in efficiency has been attributed to, in part, to alloying the CdTe with cadmium selenide $(\mathrm{CdSe})$ [2]. When CdTe (bandgap $1.50 \mathrm{eV}$ ) [3] is alloyed with $\mathrm{CdSe}$ (bandgap $1.74 \mathrm{eV}$ ) [4] and treated, a bowing effect occurs and a bandgap of $1.36 \mathrm{eV}$ presents when the mole fraction $(\mathrm{x})$ of CdSe is 0.4. This is described by Vegard's law where $b$ is the bowing factor (Fig. 1) [5], [6].

$$
E_{g, C S T}=x E_{g, C d T e}+(1-x) E_{\mathrm{g}, \mathrm{CdS}}-b x(1-x)
$$

This has been attributed to the Se substituting Te sites in the CdTe layer [7] with the ternary compound CST forming. The

Funding provided through a studentship from the EPSRC CDT in New and Sustainable Photovoltaics. Sponsorship provided by the EPSRC SuperSolar Network lower bandgap allows a greater portion of the solar spectrum to be utilized which effectively raises the short circuit current density $\left(\mathrm{J}_{\mathrm{sc}}\right)$. In our previous work chemical bath deposition (CBD) of the CdSe layer has been shown to produce CST devices with good initial efficiencies [8] however the rate is very slow with films of $280 \mathrm{~nm}$ deposited in 4 hours. Pulsed DC magnetron sputtering offers a way of giving uniform thin films at a much faster rate with better control over the process. This study will compare the microstructure and electronic properties of CdSe deposited by sputtering and CBD, as well as final device properties.

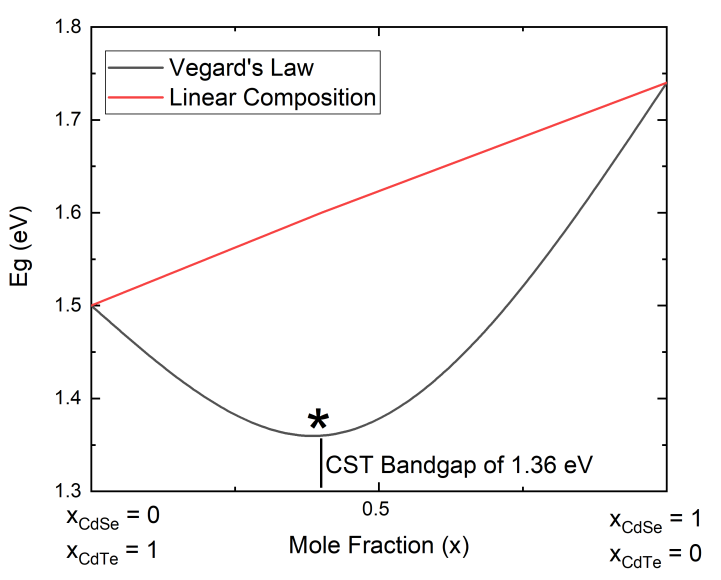

Fig. 1. Bandgap bowing described by Vegard's law. 


\section{EXPERIMENTAL}

\section{A. CdSe Deposition}

The chemical bath deposition followed a method previously reported [8] and was optimized to increase the deposition rate. $4 \mathrm{mmol}$ of cadmium acetate, $8 \mathrm{mmol}$ of sodiumselenosulphite and $10 \mathrm{ml}$ of ammonium hydroxide were added to $275 \mathrm{ml}$ of de-ionized water. Pilkington $\mathrm{TEC}^{\mathrm{TM}} 12 \mathrm{D}$ low iron glass substrates, with a F-doped $\mathrm{SnO}_{2}, \mathrm{SnO}_{2}$ buffer layer (FTO) were inserted vertically into the bath and kept at $88^{\circ} \mathrm{C}$ for 2 hours under stirring.

The sputtered CdSe films were deposited using a pulsed DC magnetron sputtering system. The process was optimized to give the fastest rate that would still result in a film quality that could be used in a full device. The deposition was completed under the following conditions, $60 \mathrm{sccm}$ of Ar gas flow giving a gas pressure of 4.2 mTorr, power density $5.5 \mathrm{~W} \mathrm{~cm}$, frequency of $250 \mathrm{kHz}, 15 \mathrm{~s}$ ramping time, to reach full power, $1.5 \mu$ s reverse time and a base pressure of $2.2 \times 10^{-5}$ Torr.

\section{B. Device Fabrication}

The devices were then completed with a $2-4 \mu \mathrm{m} \mathrm{CdTe}$ layer deposited using close space sublimation (CSS) with a substrate temperature of $515^{\circ} \mathrm{C}$, a source temperature of $630^{\circ} \mathrm{C}$ for 3 minutes deposition time at a pressure of 1 Torr with a $6 \%$ oxygen in argon gas mix. This was followed by a $\mathrm{CdCl}_{2}$ treatment at $425^{\circ} \mathrm{C}$ for 1 minute. The devices were completed with $85 \mathrm{~nm}$ thick gold back contacts, deposited using thermal evaporation. No intentional copper doping was included in these devices.

\section{RESUlTS AND DisCUSSION}

\section{A. CdSe Layer Characterization}

Scanning electron microscope (SEM) cross sections were obtained for both samples. The sputtered sample (Fig. 2a) shows a dense uniform thin film approximately $400 \mathrm{~nm}$ thick with no pinholes or voids present.

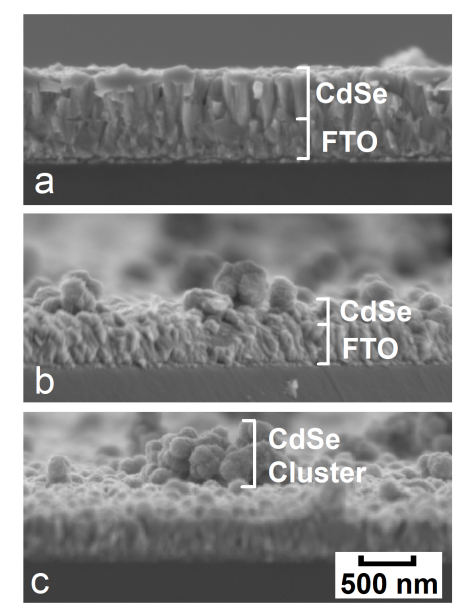

Fig. 2. SEM images of the DC sputtered (a) and CBD CdSe thin films (b) and (c).
Conversely the CBD samples were very uneven and crystallites ranged in size up to $500 \mathrm{~nm}$ and were not densely packed. CdSe clusters are shown over $500 \mathrm{~nm}$ taller than the surrounding CdSe layer (Fig. 2c). A CdSe sample deposited using CBD with an average thickness of approximately 400 $\mathrm{nm}$ was selected for further comparisons with sputtered films.

Transmission data collected was used to estimate the bandgap of the CdSe layers using a Tauc plot [9] (Fig. 3). The film deposited using CBD gave a bandgap of $1.91 \mathrm{eV}$ whilst the sputtered film gave a bandgap of $1.68 \mathrm{eV}$.

$\mathrm{X}$-ray diffraction (XRD) analysis was also completed on each film (Fig. 4) with diffraction peaks of the CBD deposited film observed at $2 \theta$ values of $24.4^{\circ}, 25.5^{\circ}, 26.5^{\circ}$ and $42.5^{\circ}$ which can be indexed to (100), (002), (101) and (110) CdSe hexagonal crystal planes (PDF 08-0459).

The sputtered thin film was seen to have both hexagonal and cubic character with diffraction peaks observed at $2 \theta$ values of $23.9^{\circ}, 26.6^{\circ}, 45.6^{\circ}$ indexed to (100), (101) and (103) hexagonal and $2 \theta$ values of $25.4^{\circ}, 41.9^{\circ}, 49.8^{\circ}$ indexed to (111), (220) and (311) (cubic PDF 65-2891)

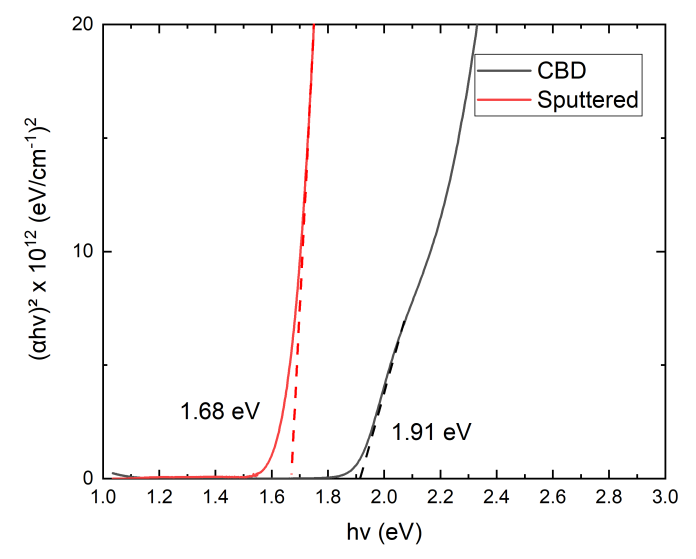

Fig. 3. Tauc plots of as-deposited thin film CdSe by CBD and DC sputtering.

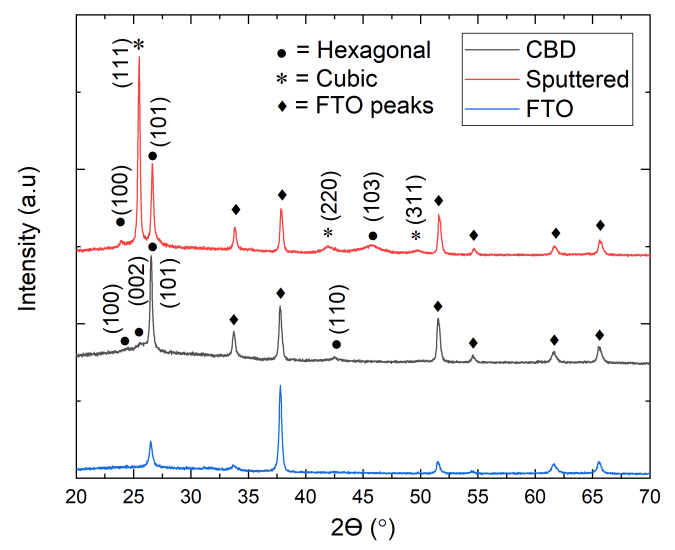

Fig. 4. XRD of as-deposited thin film CdSe by CBD and DC sputtering, The FTO XRD has been included for comparison. 
TABLE I

EFFICIENCY $(\eta)$, SHORT CIRCUIT CURRENT DENSITY ( $\left.\mathrm{J}_{\mathrm{SC}}\right)$, OPEN CIRCUIT VOLTAGE $\left(\mathrm{V}_{\mathrm{OC}}\right)$, AND FILL FACTOR (FF) OF THE CBD AND SPUTTERED CDSE/CDTE DEVICES

\begin{tabular}{|c|c|c|c|c|}
\hline CdSe deposition & $\eta(\%)$ & $\mathrm{J}_{\mathrm{sc}}\left(\mathrm{mA} \mathrm{cm}^{-2}\right)$ & $\mathrm{V}_{\mathrm{oc}}(\mathrm{mV})$ & $\mathrm{FF}(\%)$ \\
\hline \hline CBD & 9.3 & 23.3 & 696 & 57 \\
\hline DC sputtered & 3.2 & 7.4 & 682 & 63 \\
\hline
\end{tabular}

\section{B. Full Device Characterization}

Efficiency, $(\eta)$, open circuit voltage $\left(\mathrm{V}_{\mathrm{oc}}\right)$, short circuit current density $\left(\mathrm{J}_{\mathrm{sc}}\right)$ and fill factor $(\mathrm{FF})$ were measured for each device and are shown in Table I. The efficiency for the device using CBD deposited CdSe was higher than the sputtered CdSe device, with the sputtered device only achieving a $\mathrm{J}_{\mathrm{sc}}$ of 7.4 $\mathrm{mA} \mathrm{cm}^{-2}$. Although it suffered from a low $\mathbf{J}_{\mathrm{sc}}$, it did have comparable $\mathrm{V}_{\text {oc }}$ at $682 \mathrm{mV}$ and an improved $\mathrm{FF}$ of $63 \%$.

An EQE of both devices (Fig. 5), shows that the device using CdSe deposited by CBD had no parasitic absorption at short wavelengths, which suggests the CdSe diffused fully into the CdTe layer. The increased response at $850 \mathrm{~nm}$ and $900 \mathrm{~nm}$ is due to the reduction in the absorber bandgap when compared to $\mathrm{CdTe} / \mathrm{CdS}$ devices.

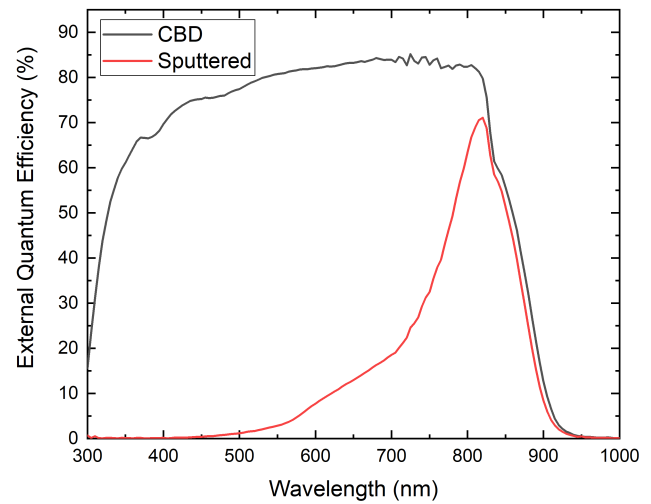

Fig. 5. EQE of the $\mathrm{CdSe} / \mathrm{CdTe}$ devices using $\mathrm{CdSe}$ deposited by $\mathrm{CBD}$ and DC sputtering.

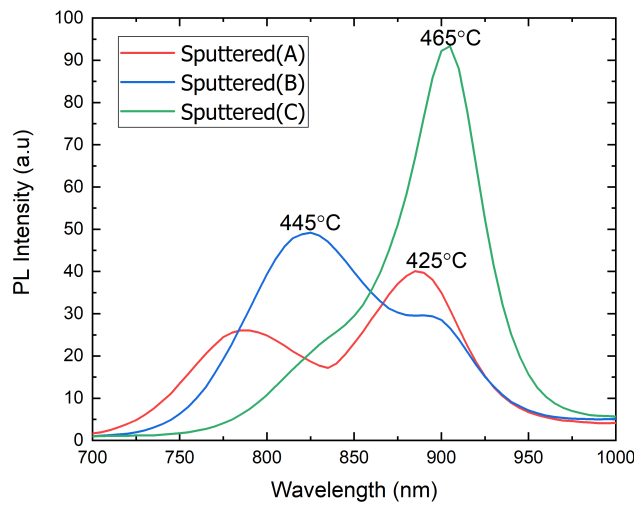

Fig. 6. PL measurements of DC sputtered CdSe devices, $\mathrm{CdCl}_{2}$ treated at variable temperatures.

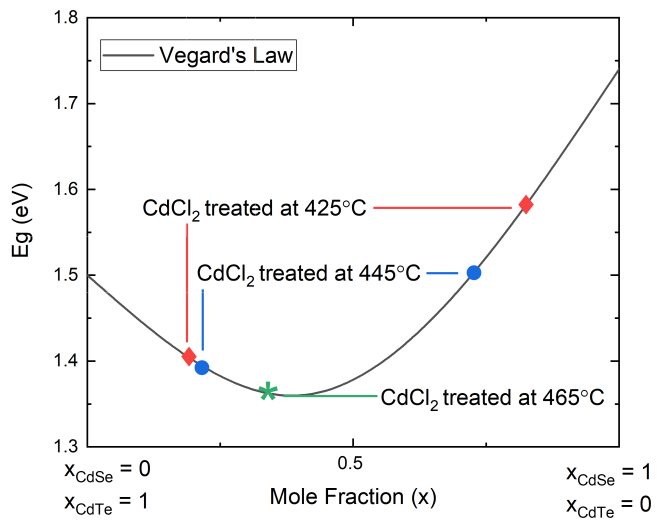

Fig. 7. Bandgaps of variable temperature treatment of $\mathrm{CdCl}_{2}$ plotted on the Vegard's law graph.

In comparison the sputtered device has a poor EQE with little response at shorter wavelengths suggesting low diffusion of the CdSe layer. Only at wavelengths greater than the CdSe bandgap does the EQE improve to $75 \%$.

It was anticipated that increasing the temperature of the $\mathrm{CdCl}_{2}$ treatment would improve the diffusion of CdSe into CdTe for the sputtered CdSe device and so was repeated at temperatures of $445^{\circ} \mathrm{C}$ and $465^{\circ} \mathrm{C}$. Photoluminescense (PL) was used to investigate opto-electronic properties of the material (Fig. 6). At $425^{\circ} \mathrm{C}$ two peaks were noted corresponding to $1.58 \mathrm{eV}$ and $1.40 \mathrm{eV}$, at $445^{\circ} \mathrm{C}$ peaks can be seen corresponding to $1.50 \mathrm{eV}$ and $1.38 \mathrm{eV}$.

The PL completed on the film annealed at $465^{\circ} \mathrm{C}$ had a large peak corresponding to $1.37 \mathrm{eV}$. When these values are plotted on the graph from Fig. 1 (Fig. 7) it is clear that increasing the temperature improves diffusion as the bandgap tends towards $1.36 \mathrm{eV}$ as the mole fraction of $\mathrm{CdSe}$ approaches 0.4.

$\mathrm{J}-\mathrm{V}$ measurements of the increased $\mathrm{CdCl}_{2}$ treatment temperatures (Fig. 8) showed that when the treatment temperature was raised to $445^{\circ} \mathrm{C}$ it resulted in a decrease in $\mathrm{V}_{\mathrm{oc}}, \mathrm{J}_{\mathrm{sc}}, \mathrm{FF}$ and efficiency but when increased to $465^{\circ} \mathrm{C}$ a slight recovery in $J_{\mathrm{sc}}$ and overall efficiency was seen (Fig. 9.)

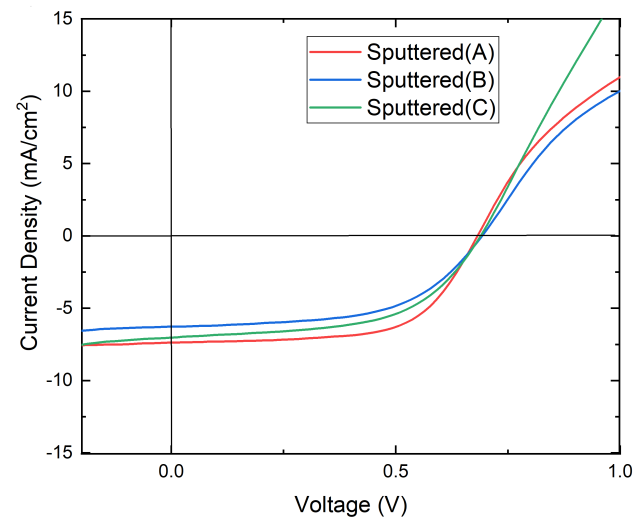

Fig. 8. JV curves of the $\mathrm{CdCl}_{2}$ treated $\mathrm{CdSe} / \mathrm{CdTe}$ devices using DC sputtered CdSe. 

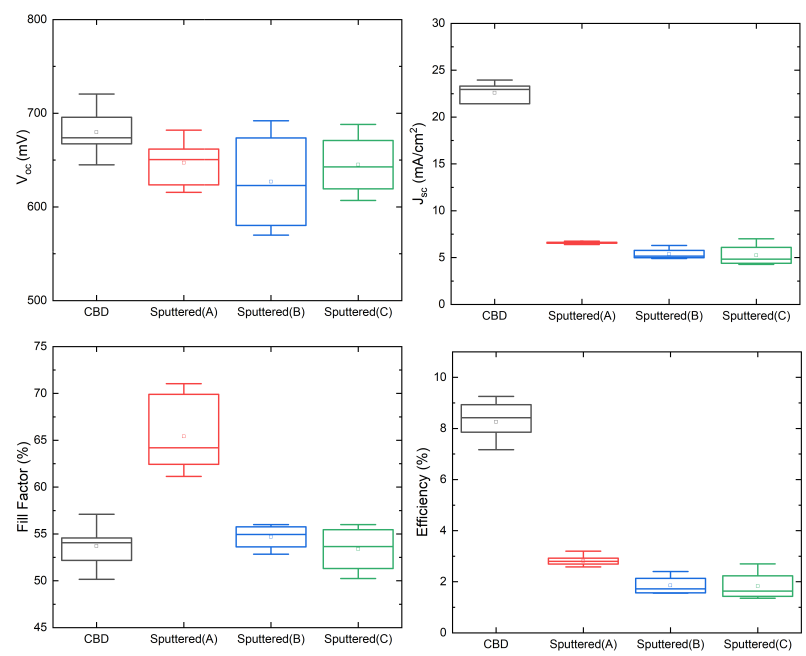

Fig. 9. Box plots showing Efficiency $(\eta)$, short circuit current density $\left(\mathrm{J}_{\mathrm{sc}}\right)$, open circuit voltage $\left(\mathrm{V}_{\mathrm{oc}}\right)$, and fill factor $(\mathrm{FF})$ of the CBD and DC sputtered $\mathrm{CdSe} / \mathrm{CdTe}$ devices with variable $\mathrm{CdCl}_{2}$ treatment temperatures.

The rollover was also improved which suggests the higher temperature was beneficial for the CdTe/back contact interface.

\section{Summary}

CdSe films deposited by CBD and pulsed DC magnetron sputtering were compared. CBD films tend towards a hexagonal crystal structure with low density and uneven surface with a large range of crystallite sizes. The bandgap of the CBD CdSe film was estimated to be $1.91 \mathrm{eV}$ using transmission data. The CBD full device showed effective diffusion of the CdSe layer into $\mathrm{CdTe}$ at a $\mathrm{CdCl}_{2}$ annealing temperature of $425^{\circ} \mathrm{C}$ with a top efficiency of $9.3 \%$ but a low FF. Both the ease of diffusion and the low FF may be attributed to low CdSe film density which resulted in a low shunt resistance but further analysis is required.

Sputtering provided a highly uniform dense film that had both hexagonal and cubic character. The bandgap was estimated to be $1.68 \mathrm{eV}$ using transmission data. The sputtered device showed low diffusion at a $\mathrm{CdCl}_{2}$ treatment temperature of $425^{\circ} \mathrm{C}$ with a poor EQE response. PL was used to analyze the opto-electronic response of sputtered devices annealed at $425^{\circ} \mathrm{C}, 445^{\circ} \mathrm{C}$ and $465^{\circ} \mathrm{C}$.

At $465^{\circ} \mathrm{C}$ a single peak occurred at $1.37 \mathrm{eV}$. This suggests as the annealing temperature increases diffusion is more efficient as the signal tends towards one large peak close to the expected bandgap for CST of $1.36 \mathrm{eV}$.

Further work will focus on improving the deposition procedure for the sputtered CdSe thin-film and film thickness to promote the most effective diffusion and analyzing higher temperatures and longer $\mathrm{CdCl}_{2}$ treatment times.

\section{REFERENCES}

[1] M. A. Green, E. D. Dunlop, D. H. Levi, J. Hohl-Ebinger, M. Yoshita, and A. W. Ho-Baillie, "Solar cell efficiency tables (version 54)," Progress in Photovoltaics: Research and Applications, vol. 27, pp. 565-575, Jul 2019.
[2] R. M. Geisthardt, M. Topic, and J. R. Sites, "Status and potential of CdTe solar-cell efficiency," IEEE Journal of Photovoltaics, vol. 5, pp. 12171221, Jul 2015.

[3] S. Rühle, "Tabulated values of the Shockley-Queisser limit for single junction solar cells," Solar Energy, vol. 130, pp. 139-147, Jun 2016.

[4] S. Ninomiya and S. Adachi, "Optical properties of cubic and hexagonal CdSe," Journal of Applied Physics, vol. 78, no. 4681, 1995.

[5] T. Baines, G. Zoppi, L. Bowen, T. P. Shalvey, S. Mariotti, K. Durose, and J. D. Major, "Incorporation of CdSe layers into CdTe thin film solar cells," Solar Energy Materials and Solar Cells, vol. 180, pp. 196-204, Jun 2018.

[6] L. Vegard, "Die konstitution der mischkristalle und die raumfülung der Atome," Zeitschrift für Physik, vol. 5, pp. 17-26, Jan 1921.

[7] T. A. M. Fiducia, B. G. Mendis, K. Li, C. R. M. Grovenor, A. H. Munshi, K. Barth, W. S. Sampath, L. D. Wright, A. Abbas, J. W. Bowers, and J. M. Walls, "Understanding the role of selenium in defect passivation for highly efficient selenium-alloyed cadmium telluride solar cells," Nature Energy, vol. 4, pp. 504-511, Jun 2019.

[8] K. M. Morris, C. Potamialis, F. Bittau, J. W. Bowers, and J. M. Walls, "Chemical bath deposition of thin film CdSe layers for use in Se alloyed CdTe solar cells," IEEE Journal of Photovoltaics, in press.

[9] J. Tauc, "Optical properties and electronic structure of amorphous Ge and Si," Materials Research Bulletin, vol. 3, pp. 37-46, Jan 1968. 